\title{
A Hierarchical Linear Modeling of the Effects of School characteristics on Students' Academic Achievement in Busia County, Kenya
}

\section{Manasi Echaune (PhD)}

County Quality Assurance and Management Officer, Department of Education and Vocational Training- County Government of Busia, Kenya

\section{ARTICLE INFO}

Article No.: 030818036

Type: Research

DOI: 10.15580/GJER.2018.2.030818036

\section{Submitted: 08/03/2018}

Accepted: 26/03/2018

Published: $30 / 03 / 2018$

${ }^{*}$ Corresponding Author

Manasi Echaune

E-mail: echaunemanasi@

yahoo.com

Phone: +2540700559147

\section{ABSTRACT}

Studies on school effectiveness have dominated educational research over the past decade, but still there is much that needs to be done. In an attempt to contribute to knowledge on school effectiveness, this study examined the effects of school characteristics namely; school size, location and school type (day, boarding and coeducational) on students' academic achievement in the Kenya Certificate of Secondary Education (KCSE) examination in Busia County, Kenya. A two level hierarchical linear modeling (HLM) technique was employed with student predictors at level 1 and school characteristics at level 2. A sample of 755 students who were drawn from 100 secondary schools participated in the study. Findings of the study demonstrated that school type, location and size of the school had no statistically significant effects on students' academic achievement in Kenya Certificate of Secondary Education examination. The findings of the study give implication that parents should not have the perception that school characteristics influence their children's academic achievement.

Keywords: Hierarchical Linear

Modeling, School characteristics,

Academic achievement 


\section{INTRODUCTION}

Over the past decade, most countries have increased the national budget for education with a view to expand access, promote retention and improve learning outcomes. A survey of studies across the world revealed that significant gains have been made in regard to access and retention but less has been achieved in relation to learning outcomes. Abreh (2015) noted that in most countrieslearning outcomes remain unsatisfactory but even then the problem may not be limited to third world countries. For instance, even in highly developed countries such as Canada and Finland where education system are hailed to be more efficient and equitable, there are still concerns of quality of education (OECD, 2010; UNESCO, 2014). Since there is enough evidence showing that most countries have almost achieved universal access, the focus for most of the countries now shifts to ensuring that learners access quality education and attain desirable outcomes that meet their needs.

The Coleman study on the Equality of Educational Opportunity in the sixties is probably among the most significant attempts to explore the causes of inequity in educational outcomes (Coleman, 1966). The study demonstrated that school type, school location and school size had statistically significant effects on learning outcomes. Sugden (2012); Joan (2009); Anditi, Okere and Muchiri (2014) reckoned that there was a positive relationship between type of school and students' academic achievement. Saidin and Brahim (2013) reported that presence of boys in a classroom had negative effect on girls' academic achievement. Kang, Lee and Niederle (2014) instead reported that type of school had no significant effect on student academic achievement in South Korea. In Turkey, Brock (2016) employed a multilevel analysis to investigate the causes of inequalities among seventh and eighth grade students' academic achievement. The multilevel approach enabled the researcher to estimate apportion variation in student academic achievement to various independent variables. The study predicted that $17 \%$ of the variation in student test scores was explained by differences between schools while the remaining variation was accounted by the withinschool factors. The type of school attended explained approximately $5 \%$ of the variation in students' academic achievement. Dambudzo (2013) found that students in boarding schools had a higher self concept that made them perform better than their colleagues in non boarding schools.

In Rwanda, Zhahibimana (2010) found that there was a statistically significant difference in academic achievement among students attending public schools and their counterparts in private schools. In Uganda, Nyamongo (2014) reported that there was a statistically significant difference in academic achievement of students attending rural and urban schools. In Kenya, Mburu (2013) reported that single-sex secondary schools recorded a higher number of students enrolling in university and other tertiary institutions. Epari, Othuon and Khasenye (2016) demonstrated that type of school had statistically significant effect on students' scores in KCPE examination. Students in boarding schools attained higher scores compared to their counterparts in day schools. Kang, Lee and Niederle (2014) also reported a significant positive effect of type of school on students' academic achievement.

The question of whether the location of a school influences learning outcomes has continued to dominate debate on school effectiveness. Some studies found a significant relationship between school location and academic achievement while others have reported otherwise. In Malaysia, Gul and Shaheen (2014) while examining the effects of school location found that location of a school accounted for up to 19.6 percent of variation in student academic achievement in mathematics. The works of Koroye (2016) demonstrated that there was a statistically significant difference in students' academic achievement among rural and urban secondary schools in senior school certificate examinations in Nigeria. Meanwhile, Omotade and Olusola (2014) also reported similar results but Mersch (2012) reported contrary findings. The study indicated that location of a school had no statistically significant effect on students' academic achievement in the USA. However, findings of this study were consistent with Adeoye and Tayo (2010). In Kenya a study by Odumbe, Simatwa and Ayodo (2014) also revealed that school location had significant effect on academic achievement.

There is no agreement as to what constitutes a large or small school. However, most commentators think that an optimal school should enroll between 400 and 500 student (Ndiritu, 2012). As to whether school size influences educational outcomes, Sun, et.al, (2012) demonstrated that small classes improved learning outcomes. Menge (2014) on the other hand demonstrated that overcrowded classrooms made it difficult for teachers to move around the classroom and the teacher was therefore unable to provide individualized student instruction. This is supported by Akabogu and Ajiwoju (2014) who reported that large class had a statistically significant but negative effect on students' academic achievement. Waita (2012) too found that there was a statistically significant negative correlation between class size and academic achievement. The current study adopted hierarchical linear modeling to analyze school effects on school effects on learning outcomes in secondary education in Busia County, Kenya.

Secondary education in Kenya is critical in preparing learners for further training and the job market. It is worrying that despite the many studies on school effectiveness it is still not clear why secondary students in Busia County continue to perform poorly in national examinations. In the past years, less than $10 \%$ of the students who sit for the Kenya Certificate of Secondary Education examination normally attain grades that allow admission to university. In 2017, 7550 students registered for the KCSE examination. During that yearonly 849 students scored $\mathrm{C}_{+}$(Plus) the mandatory grade for admission into university. No student scored an A (plain) and only 15 students scored A- (Minus). Majority of the students who sat for that year's examination were in the lower quartile, 860 scored C (plain), 1264 scored C-(minus) and the rest below $\mathrm{D}+$ (plus). The probable cause of the decimal achievement has continued to dominate public debate. Even then some studies have suggested that school variables are to blame for the unsatisfactory 
achievement while others have blamed student characteristics. This study recons that the controversy surrounding the unsatisfactory academic achievement was probably a product of the statistical approaches employed. For most of the reviewed studies, the hierarchical nature of educational data was ignored and as a result the findings could have been inaccurate. The current study adopted hierarchical linear modeling to analyze the school effects on students' academic achievement in secondary education in Busia County, Kenya.

\subsection{Objective of the Study}

The study sought to establish the effect of school characteristics on students' academic achievement in KCSE examination in Busia County, Kenya

\subsection{Hypothesis of the Study}

School characteristics have no statistically significant effect on students' academic achievement in KCSE examination in Busia, County Kenya

\subsection{Conceptual Framework}

The conceptual framework adopted by the study is as shown in Figure 1. Figure 1 demonstrates that student learning outcomes were a function of level 1 variable (student characteristics) and level 2 variables (school characteristics, teacher inputs and non teacher inputs). The study employed Hierarchical Linear Modeling (HLM) technique to isolate the school effects on students' academic achievement in KCSE examination.

Independent variables Dependent variable

Student Characteristics and School

Predictors

Student characteristics

- Prior achievement

- Parental involvement

- Student's gender

- Student's age

- Familv size

School characteristics

- School type

- Location of school

- School size

Teacher inputs

-Teacher- teacher relationship

-Number of TSC teachers

-Number of BoM teachers

-Teacher -student relationship

-Teacher teamwork

-Teachers assist weak students

School Non Teacher Inputs

- Physical facilities

- Text books

- ICT facilities

- Boarding facilities

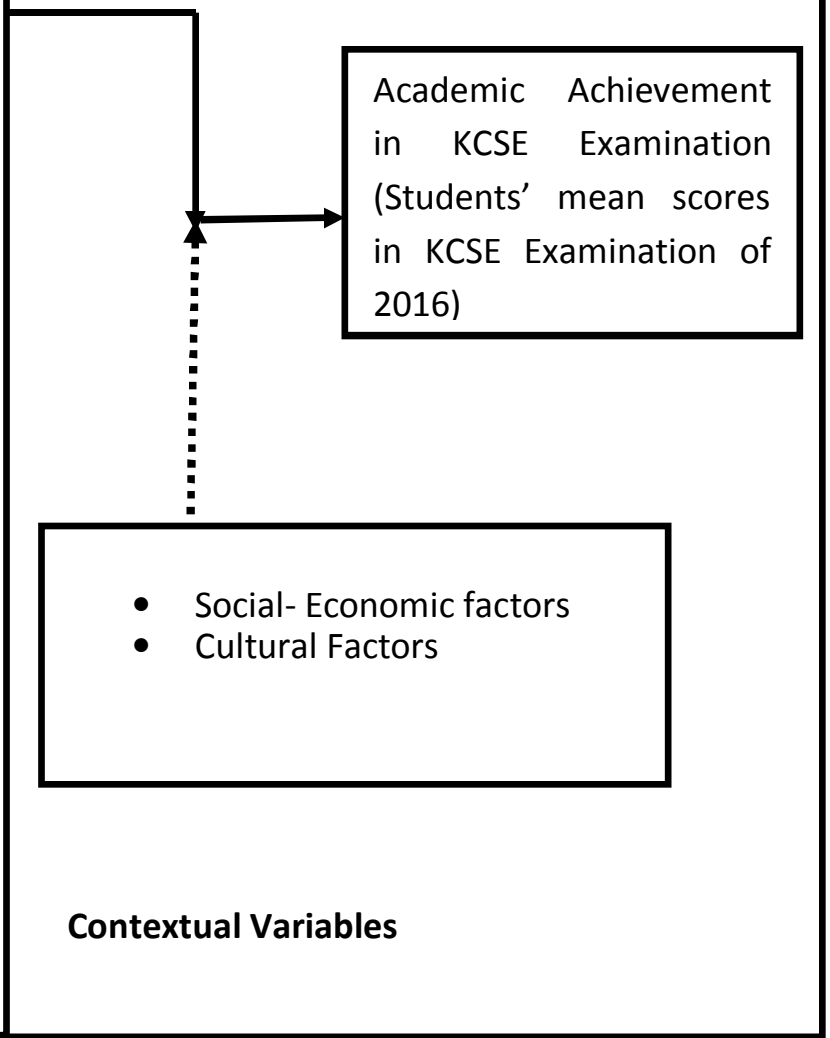

Figure 1: Hierarchical Linear Modeling of the effects of school characteristics on students' academic achievement in Busia County, Kenya. 


\section{RESEARCH DESIGN AND PROCEDURE}

The study was carried out in Busia County, Kenya. Busia County is located in the Western part of Kenya and itcomprises of seven Sub Counties namely; Nambale, Teso North, Teso South, Butula, Funyula, Budalangi, and Matayos. The County touches the Republic of Uganda on the West lying between latitude 0 을 0.45 North and longitude $34^{\circ} 25$ east. It is approximately $1694.5 \mathrm{~km}^{2}$. The study employed a descriptive survey research design. The County had a total of 152 registered secondary schools with total enrolment of 9480 students. The study employed a descriptive survey design. This design was preferred because the study merely sought to establish facts as they are without manipulating any variable. Simple random sampling was employed to draw the sample of teachers and students while purposive sampling was used to draw the sample of principals. A sample of 855 students, 344 teachers and 100 principals was used. Teachers and the principals were used to provide information on level 2 variables (school based variables) such as availability of physical facilities and text books while students provided information on the student level variables such as student age, gender and level of parental involvement.

This study sought to establish the extent of the differences in average KCSE examination results between schools that were accounted for by variables such as student prior achievement, age, gender, student's parent involvement, average class size, school types (day, boarding, co-educational) and location of schools. Students were considered as level 1 unit while schools were level 2 units. The level 1 predictors were student prior achievement, age, gender and student's parent involvement. The level 2 predictors were average class size, school types (day, boarding, co-educational) and location of schools. In this case, students were nested within schools hence creating hierarchical data structure. According to Raudenbush and Bryk (2002)), the problem of nested data sets as was the case in this study, could best be dealt with using hierarchical linear modeling technique.

\section{RESULTS}

\subsection{Variables Used in the Study}

Table 1 shows the description of the variables used to carry out hierarchical linear modeling of effects of school characteristics on students' academic achievement in KCSE in Busia County, Kenya. 


\begin{tabular}{|c|c|c|c|}
\hline Var. & Variable Label & Variable scale & Variable values \\
\hline a1z & Student's KCSE z-score & Ratio & $-2.04-2.59$ \\
\hline a1a & Female student & Nominal & $0=$ Male; $1=$ Female \\
\hline a1c & $\begin{array}{lll}\begin{array}{l}\text { Student's } \\
\text { achievement }\end{array} & \text { prior } & \text { academic } \\
\end{array}$ & Interval & $150-410$ \\
\hline a2a & $\begin{array}{l}\text { Student's parent involved in } \\
\text { discussing academic }\end{array}$ & Interval & $\begin{array}{l}0=\quad \text { Nonexistent } 4=\text { Fully } \\
\text { existent }\end{array}$ \\
\hline$a 2 b$ & $\begin{array}{l}\text { Student's parent's provision of } \\
\text { school requirements }\end{array}$ & Interval & $\begin{array}{ll}0=\quad \text { Nonexistent } & 4=\text { Fully } \\
\text { existent } & \end{array}$ \\
\hline a2c & $\begin{array}{l}\text { Student's parent involved in } \\
\text { attendance of meetings }\end{array}$ & Interval & $\begin{array}{l}0=\quad \text { Nonexistent } 4=\text { Fully } \\
\text { existent }\end{array}$ \\
\hline s0e & Rural school & Nominal & $\begin{array}{l}0=\text { Urban school; } 1=\text { Rural } \\
\text { school }\end{array}$ \\
\hline s2a & Boys secondary schools & Dummy & $\begin{array}{l}0=\text { Other } \\
\text { classification; } 1=\text { Boys } \\
\text { secondary schools }\end{array}$ \\
\hline $\mathrm{s} 2 \mathrm{~b}$ & School is boarding & Nominal & $\begin{array}{l}0=\quad \text { Not Boarding; } \\
\text { Boarding School }\end{array}$ \\
\hline s2f & Number of streams & Interval & $1-6$ \\
\hline s2g & School enrolment & Interval & $144-845$ \\
\hline $\mathrm{s} 2 \mathrm{~h}$ & School mean score 2015 & Interval & $2-8.931$ \\
\hline s2i & School mean score 2016 & Interval & $2-5.992$ \\
\hline s2j & $\begin{array}{llll}\begin{array}{l}\text { Average } \\
2015 / 16\end{array} & \text { school mean } & \text { score } \\
\end{array}$ & Interval & $2.31-7.308$ \\
\hline s3p & $\begin{array}{l}\text { Students participation in co- } \\
\text { curricular }\end{array}$ & Interval & $0=$ Very poor;4=Excellent \\
\hline s2c & Number of TSC teachers & Interval & $0-28$ \\
\hline s2d & Number of BoM teachers & Interval & $4-16$ \\
\hline s2e & Total number of teachers & Interval & $8-40$ \\
\hline s3a & Teacher's lessons missed & Interval & $2-5$ \\
\hline $\mathrm{s} 3 \mathrm{~b}$ & Teachers cover missed lessons & Interval & $0=$ Not at all; $4=$ Yes, Fully \\
\hline s3c & Teachers assist weak students & Interval & $0=$ Not at all; 4=Yes, Fully \\
\hline s3d & $\begin{array}{l}\begin{array}{l}\text { Teachers adhere to code of } \\
\text { conduct }\end{array} \\
\end{array}$ & Interval & $0=$ Not at all; $4=$ Yes, Fully \\
\hline s3f & Teacher teamwork & Interval & $0=$ Very poor; 4=Excellent \\
\hline s3g & Teacher relationships & Interval & $0=$ Very poor; $4=$ Excellent \\
\hline s3h & Teacher-parent relationships & Interval & $0=$ Very poor;4=Excellent \\
\hline s3i & Teacher-student relationship & Interval & $0=$ Very poor;4=Excellent \\
\hline s3j & Teachers duty reporting time & Interval & $0=$ Very late; $4=$ Excellent \\
\hline s3k & Teachers commitment to duty & Interval & $0=$ Very poor;4=Excellent \\
\hline s3l & Availability of text books & Interval & $0=$ Very poor;4=Excellent \\
\hline s3n & Availability of physical facilities & Interval & $0=$ Not available;4=Excellent \\
\hline
\end{tabular}

Table 1 depicts the dependent variable (a1z) or the students' academic achievement in KCSE examination. The variable was based on the student's average score in the five compulsory subjectstestedin the KCSE examination. The maximum score in any of the five subjects is 12 points making a total of 60 points for all the five compulsory subjects. To arrive at the average raw scores, the total scores are divided by the number of subjects. The results also indicate that the average raw (untransformed) scores ranged from 2.31 to 7.308. These scores were then standardized by subtracting the raw scores from the mean the dividing by the standard deviation. Meanwhile the transformed scores ranged from 2.04 to 2.59 . 
3.2 Descriptive Statistics of Variables used in HLM Analysis

The study sought to estimate effects of school characteristics on students' academic achievement in
Kenya Certificate of Secondary Education examination. Table 2 presents the descriptive statistics of the variables used in the hierarchical linear modeling analysis.

\begin{tabular}{|c|c|c|c|c|c|c|}
\hline \multicolumn{7}{|c|}{ Table 2: Descriptive Statistics of Variables Used in HLM Analysis } \\
\hline Var. & Variable Label & Mean & SE(Mean) & SD & Min & Max \\
\hline a1z & Student's KCSE z-score & 0.00 & 0.03 & 1 & 2.04 & 2.59 \\
\hline a1c & Student's prior academic achievement & 274.89 & 1.29 & 37.81 & 150 & 410 \\
\hline a2a & $\begin{array}{l}\text { Student's parent involved in discussing } \\
\text { academic }\end{array}$ & 2.77 & 0.04 & 1.06 & 0 & 4 \\
\hline$a 2 b$ & $\begin{array}{l}\text { Student's parent's provision of school } \\
\text { requirements }\end{array}$ & 2.77 & 0.04 & 1.03 & 0 & 4 \\
\hline a2c & $\begin{array}{l}\text { Student's parent involved in attendance of } \\
\text { meetings }\end{array}$ & 2.69 & 0.04 & 1.05 & 0 & 4 \\
\hline s2f & Number of streams & 2.28 & 0.04 & 1.27 & 1 & 6 \\
\hline s2g & School enrolment & 374.69 & 5.78 & 168.90 & 144 & 845 \\
\hline $\mathrm{s} 2 \mathrm{~h}$ & School mean score 2015 & 4.80 & 0.05 & 1.58 & 2 & 8.931 \\
\hline s2i & School mean score 2016 & 3.42 & 0.03 & 0.92 & 2 & 5.992 \\
\hline s2j & Average school mean score $2015 / 16$ & 4.08 & 0.04 & 1.08 & 2.31 & 7.308 \\
\hline s3p & Students participation in co-curricular & 2.17 & 0.04 & 1.08 & 0 & 4 \\
\hline s2c & Number of TSC teachers & 10.37 & 0.19 & 5.69 & 0 & 28 \\
\hline s2d & Number of BOM teachers & 6.96 & 0.10 & 2.80 & 4 & 16 \\
\hline s2e & Total number of teachers & 17.34 & 0.27 & 7.78 & 8 & 40 \\
\hline s3a & Teacher's miss lessons & 3.43 & 0.03 & 0.93 & 2 & 4 \\
\hline s3b & Teachers cover missed lessons & 2.31 & 0.03 & 0.85 & 0 & 4 \\
\hline s3c & Teachers assist weak students & 2.31 & 0.03 & 0.88 & 0 & 4 \\
\hline s3d & Teachers adhere to code of conduct & 2.70 & 0.03 & 0.86 & 0 & 4 \\
\hline s3f & Teacher teamwork & 2.49 & 0.03 & 0.89 & 1 & 4 \\
\hline s3g & Teacher relationships & 2.44 & 0.03 & 0.80 & 0 & 4 \\
\hline s3h & Teacher-parent relationships & 2.55 & 0.03 & 0.90 & 0 & 4 \\
\hline s3i & Teacher-student relationship & 2.58 & 0.03 & 0.91 & 0 & 4 \\
\hline s3j & Teachers duty reporting time & 2.33 & 0.03 & 0.84 & 0 & 4 \\
\hline s3k & Teachers commitment to duty & 2.31 & 0.03 & 0.87 & 0 & 4 \\
\hline s3l & Availability of text books & 2.83 & 0.04 & 1.16 & 0 & 4 \\
\hline s3n & Availability of physical facilities & 2.34 & 0.04 & 1.06 & 0 & 4 \\
\hline & \multicolumn{6}{|c|}{ Nominal and Dummy Variables [Frequencies preceding percent in ()] } \\
\hline s0e & \multicolumn{6}{|c|}{$\begin{array}{l}\text { Rural school: } 0=\text { Student is in urban school, } 312(36.49) ; 1=\text { Student is in rural school, } 543 \\
\text { (63.51) }\end{array}$} \\
\hline a1a & \multicolumn{6}{|c|}{ Female student: 0=Male, 413(60.00); 1=Female, $342(40.00)$} \\
\hline s2a3 & \multirow{2}{*}{\multicolumn{6}{|c|}{$\begin{array}{l}\text { Boys secondary schools: } 0=\text { Other classification, } 672(90.29) ; 1=\text { Boys secondary schools } 83 \\
(9.71) \\
\text { School is boardina: } 0=\text { School is not boarding } 438(51.23): 1=\text { School is boarding } 417(48.77)\end{array}$}} \\
\hline $\mathrm{s} 2 \mathrm{~b}$ & & & & & & \\
\hline
\end{tabular}

The results of the study displayed in Table 2 indicate that the KCSE z-score was 0.00 with standard error of the mean of 0.03 , standard deviation of 1 . Student prior achievement ranged between 150 and 410 . The results also indicate that the largest secondary school in the County had eight streams. In addition, school enrolment ranged from 144-845 students. 


\subsection{Bivariate Analysis of Relationship betweenthe Dependent and Independent Variables}

Pair wise correlation was carried out to analyze the relationship between students' academic achievement in KCSE examination and selected school characteristics. The correlation results are presented in Table 3.

\begin{tabular}{|c|c|c|c|c|c|c|c|c|c|}
\hline \multicolumn{10}{|c|}{$\begin{array}{c}\text { Table 3: Pair-Wise Correlation between Student KCSE z Score and Selected School Level } \\
\text { Variables }\end{array}$} \\
\hline Var. & Variable & & a1z & s0e & s2a3 & $\mathrm{s} 2 \mathrm{~b}$ & s2f & s2g & $\mathrm{s} 2 \mathrm{~h}$ \\
\hline a1z & Student's KCSE z-score & $a$ & 1 & & & & & & \\
\hline \multirow[t]{2}{*}{$\mathrm{s} 0 \mathrm{e}$} & Rural school & $\mathrm{a}$ & -0.219 & 1 & & & & & \\
\hline & & $\mathrm{b}$ & $<.001$ & & & & & & \\
\hline \multirow[t]{2}{*}{ s2a } & Boys secondary schools & a & 0.072 & -0.301 & 1 & & & & \\
\hline & & $\mathrm{D}$ & 0.035 & $<.001$ & & & & & \\
\hline \multirow[t]{2}{*}{$\mathrm{s} 2 \mathrm{~b}$} & School is boarding & $\mathrm{a}$ & 0.175 & -0.412 & 0.336 & 1 & & & \\
\hline & & b & $<.001$ & $<.001$ & $<.001$ & & & & \\
\hline \multirow[t]{2}{*}{$s 2 f$} & Number of streams & a & 0.296 & -0.340 & 0.301 & 0.463 & 1 & & \\
\hline & & 5 & $<.001$ & $<.001$ & $<.001$ & $<.001$ & & & \\
\hline \multirow[t]{2}{*}{ s2g } & School enrolment & $a$ & 0.304 & -0.351 & 0.350 & 0.404 & 0.952 & 1 & \\
\hline & & b & $<.001$ & $<.001$ & $<.001$ & $<.001$ & $<.001$ & & \\
\hline \multirow[t]{2}{*}{$\mathrm{s} 2 \mathrm{~h}$} & School mean score 2015 & a & 0.232 & -0.208 & 0.129 & 0.392 & 0.652 & 0.597 & 1 \\
\hline & & $b$ & $<.001$ & $<.001$ & $<.001$ & $<.001$ & $<.001$ & $<.001$ & \\
\hline \multirow[t]{2}{*}{ s2i } & School mean score 2016 & $\mathrm{a}$ & 0.143 & -0.205 & 0.227 & 0.414 & 0.492 & 0.508 & 0.493 \\
\hline & & b & $<.001$ & $<.001$ & $<.001$ & $<.001$ & $<.001$ & $<.001$ & $<.001$ \\
\hline \multirow[t]{2}{*}{ s2j } & $\begin{array}{l}\text { Average school mean } \\
\text { score 2015/16 }\end{array}$ & a & 0.208 & -0.223 & 0.203 & 0.446 & 0.652 & 0.609 & 0.894 \\
\hline & & b & $<.001$ & $<.001$ & $<.001$ & $<.001$ & $<.001$ & $<.001$ & $<.001$ \\
\hline \multirow[t]{2}{*}{ s3p } & $\begin{array}{l}\text { Students participation in } \\
\text { co-curricular }\end{array}$ & a & 0.082 & -0.053 & 0.007 & 0.052 & 0.008 & 0.046 & 0.022 \\
\hline & & D & 0.017 & 0.123 & 0.829 & 0.132 & 0.818 & 0.176 & 0.515 \\
\hline
\end{tabular}

\subsection{Unconditional (Intercept-only) Model}

The first step in fitting hierarchical linear models is to run an unconditional (intercept-only, null or empty) model. The unconditional model forms the basis for developing the regression models. An unconditional model is ideally a one-way ANOVA model. As the name suggests, the model excludes all predictor (independent) variables. A model with only an intercept as a predictor was therefore formulated at level 1, student level or within-school level. The results of the unconditional model are presented in Table 4. In this model, 755 students were nested within
100 schools. The outcome variable was transformed to a standard normal score with a mean of zero (0); standard deviation and variance of one (1). This transformation was necessary so that the residuals at each level could better approximate the normality assumptions of the models. According to Leckie (2013) and Raudenbush and Bryk (2002) such transformation would also allow interpretation of the effects of covariates in hierarchical linear models in terms of standard deviation units of the outcome variable. Table 4 presents the results of the unconditional model 


\begin{tabular}{|c|c|c|c|c|}
\hline \multicolumn{5}{|c|}{ Table 4: Two Level Unconditional (Empty) } \\
\hline \multicolumn{2}{|c|}{ Fixed Effect } & & & \\
\hline Variable & Variable label & \multicolumn{2}{|l|}{ Null Model } & \\
\hline & & Est. (Std. Err.) & $P$ & \\
\hline & Intercept, $\beta_{0 j}$ & $0.012(0.078)$ & 0.874 & \\
\hline \multicolumn{2}{|c|}{ Random Effect } & Variance Component & & \\
\hline \multicolumn{2}{|c|}{ Student (Level-1), $e_{i j}$} & $0.4116(0.02)$ & & \\
\hline \multicolumn{2}{|c|}{ School (Level-2), $u_{j}$} & $0.5426(0.08)$ & & \\
\hline \multicolumn{4}{|c|}{ Variance Partition Coefficient (VPC) } & \\
\hline \multicolumn{2}{|c|}{ Student (Level-1), $\sigma_{\mathrm{e}}^{2}$} & 0.4314 & & \\
\hline \multicolumn{2}{|c|}{ School (Level-2), $\sigma_{u}^{2}$} & 0.5686 & & \\
\hline \multicolumn{4}{|c|}{ Model Fit Statistics } & \\
\hline \multicolumn{2}{|l|}{ Deviance } & 1913 & & \\
\hline \multicolumn{2}{|c|}{ Akaike Information Criterion (AIC) } & 1919 & & \\
\hline \multicolumn{2}{|c|}{ Bayesian Information Criterion (BIC) } & 1933 & & \\
\hline \multicolumn{2}{|c|}{ Likelihood Ratio test vs. OLS Regression } & chibar2 $(01)=513$ & $<.001$ & \\
\hline \multicolumn{4}{|c|}{$\begin{array}{l}\text { Note. } N=755 \text {; Est. = Estimate; Std. Err. = Standard Error (in parentheses); AIC and BIC } \\
\text { statistics = smaller-is-better fit; OLS=Ordinary Least Squares }\end{array}$} & \\
\hline
\end{tabular}

From this study, Table 4 depicts that the overall student mean academic achievement in the2017 KCSE examination across all schools in Busia County was 0.012 , standard error $(\mathrm{SE})=0.078, \mathrm{p}=.874$ (random intercept, $\quad$ __0)Since the outcome variable was approximately normalized, an estimated random intercept of zero, total variance of approximately one and a non-significant intercept were expected.

The Variance Partition Component (VPC) was used to estimate variation in students' academic achievement that lay at student and school levels of the model hierarchy. The VPC was therefore used to establish the relative importance of school level predictors and students characteristics as sources of variation in academic achievement. Ordinarily, in hierarchical linear modeling, the general implication of the VPC is that when the VPC is high there are large systematic differences in student achievement scores across schools. In a conditional model, VPC is based on the residual rather than the observed responses. Table 4 depicts that the between school and within school variance in academic achievement were 0.5426 and 0.4116 respectively.
According to Hox (2010), deviance statistics estimate the lack of model adjustment and should be compared to subsequent models. For instance, with the addition of explanatory variables, model adjustment is expected to improve and the deviance is expected to decrease. Kreft and De Leeuw (1998) argue that when comparing models, a reduction in the estimates of deviance statistic in a subsequent model when predictor variables are introduced suggests that the subsequent model is a better fit of the data compared with the preceding model(s). The results provided in Table 4 depicts that the deviance, Akaike Information Criterion (AIC) and Bayesian Information Criterion (BIC) estimates for the unconditional model were 1913, 1919 and 1933 respectively.

\subsection{The Random Intercept Model for School Effects}

Table 5 presents the random intercept model for the effects of school characteristics with selected student level variables, and non teacher school inputs. By adding the predictors into the model step by step, it was possible to estimate the effects of school characteristics on students' academic achievement. 


\begin{tabular}{|c|c|c|c|c|c|c|c|c|}
\hline \multicolumn{9}{|c|}{\begin{tabular}{|c|} 
Table 5: Twc \\
\end{tabular}} \\
\hline \multicolumn{2}{|c|}{ Fixed Effect } & & & & & & & \\
\hline \multirow[t]{2}{*}{ Var. } & \multirow[t]{2}{*}{ Variable label } & \multicolumn{3}{|c|}{ Model 1 (Student) } & \multicolumn{2}{|c|}{$\begin{array}{lcc}\text { Model } & 2 \\
\text { characteristics })\end{array}$ (School } & \multicolumn{2}{|c|}{$\begin{array}{lll}\begin{array}{l}\text { Model } \\
\text { inputs })\end{array} & 3 & \text { (Schoo }\end{array}$} \\
\hline & & Est. (SE) & \multicolumn{2}{|l|}{$P$} & Est. (SE) & $P$ & Est. (SE) & $P$ \\
\hline a1a & Female student & $\begin{array}{l}0.12 \\
(0.05)\end{array}$ & \multicolumn{2}{|c|}{0.030} & $0.09(0.05)$ & 0.080 & $0.09(0.05)$ & 0.098 \\
\hline a1c & $\begin{array}{l}\text { Student's prior academic } \\
\text { achievement }\end{array}$ & $\begin{array}{l}0.00 \\
(0.00)\end{array}$ & \multicolumn{2}{|c|}{0.012} & $0.00(0.00)$ & 0.027 & $\begin{array}{l}0.00 \\
(.00)\end{array}$ & 0.030 \\
\hline a2a & $\begin{array}{l}\text { Student's parent involved in } \\
\text { discussing academic }\end{array}$ & $\begin{array}{l}0.16 \\
(0.03)\end{array}$ & \multicolumn{2}{|c|}{$<.001$} & $0.16(0.03)$ & $<.001$ & $0.16(0.03)$ & $<.001$ \\
\hline$a 2 b$ & $\begin{array}{l}\text { Student's parent's provision } \\
\text { of school requirements }\end{array}$ & $\begin{array}{l}0.15 \\
(0.03)\end{array}$ & \multicolumn{2}{|c|}{$<.001$} & $0.15(0.03)$ & $<.001$ & $0.15(0.03)$ & $<.001$ \\
\hline a2c & $\begin{array}{l}\text { Student's parent involved in } \\
\text { attendance of meetings }\end{array}$ & $\begin{array}{l}0.12 \\
(0.03)\end{array}$ & \multicolumn{2}{|c|}{$<.001$} & $0.12(0.03)$ & $<.001$ & $0.12(0.03)$ & $<.001$ \\
\hline $\mathrm{s} 0 \mathrm{e}$ & Rural school & & & & $\begin{array}{l}-0.09 \\
(0.11)\end{array}$ & 0.412 & $-0.09(0.11)$ & 0.431 \\
\hline s2a & Boys secondary schools & & & & $\begin{array}{l}-0.21 \\
(0.19)\end{array}$ & 0.250 & $-0.22(0.18)$ & 0.233 \\
\hline $\mathrm{s} 2 \mathrm{~b}$ & School is boarding & & & & $0.01(0.12)$ & 0.932 & $0.01(0.11)$ & 0.964 \\
\hline s2f & Number of streams & & & & $\begin{array}{l}-0.03 \\
(0.15) \\
\end{array}$ & 0.840 & $-0.03(0.14)$ & 0.823 \\
\hline s2g & School enrolment & & & & $0.00(0.00)$ & 0.190 & $0.00(0.00)$ & 0.162 \\
\hline $\mathrm{s} 2 \mathrm{~h}$ & School mean score 2015 & & & & $0.15(0.15)$ & 0.310 & $0.15(0.14)$ & 0.298 \\
\hline s2i & School mean score 2016 & & & & $0.13(0.18)$ & 0.474 & $0.12(0.18)$ & 0.494 \\
\hline s2j & $\begin{array}{l}\text { Average school mean score } \\
2015 / 16\end{array}$ & & & & $\begin{array}{l}-0.17 \\
(0.30)\end{array}$ & 0.561 & $-0.19(0.30)$ & 0.530 \\
\hline s3p & $\begin{array}{l}\text { Students participation in co- } \\
\text { curricular }\end{array}$ & & & & $0.01(0.02)$ & 0.659 & $0.00(0.02)$ & 0.839 \\
\hline s3f & Teacher teamwork & & & & & & $0.02(0.03)$ & 0.628 \\
\hline s3l & Availability of text books & & & & & & $-0.00(0.02)$ & 0.845 \\
\hline s3n & $\begin{array}{l}\begin{array}{l}\text { Availability of physical } \\
\text { facilities }\end{array} \\
\end{array}$ & & & & & & $0.04(0.02)$ & 0.050 \\
\hline & Intercept & $\begin{array}{l}-1.68 \\
(0.21)\end{array}$ & $<.00$ & & $\begin{array}{l}-2.41 \\
(0.33)\end{array}$ & $<.001$ & $-2.48(0.33)$ & $<.001$ \\
\hline Ranc & m Effect & Variance & omp & nent & Variance Co & mponent & Variance Co & mponent \\
\hline Stude & t (Level-1), $e_{i j}$ & $0.3577(0$. & & & $0.3575(0.02$ & & $0.3565(0.02$ & \\
\hline Scho & (Level-2), $u_{j}$ & $0.2688(0$. & & & $0.1937(0.04$ & & $0.1893(0.03$ & \\
\hline Varia & ce Explained \% (continued) & & & & & & & \\
\hline Stude & t (Level-1), $\sigma_{\mathrm{e}}^{2}$ & 0.0565 & & & 0.0567 & & 0.0578 & \\
\hline Scho & $\left(\right.$ Level-2), $\sigma_{u}^{2}$ & 0.2869 & & & 0.3656 & & 0.3702 & \\
\hline Mode & Fit Statistics & & & & & & & \\
\hline Devia & & 1743 & & & 1715 & & 1711 & \\
\hline Akaik & Information Criterion (AIC) & 1759 & & & 1749 & & 1751 & \\
\hline Baye & an Information Criterion (BIC) & 1797 & & & 1830 & & 1846 & \\
\hline $\begin{array}{l}\text { Likeli } \\
\text { Regr }\end{array}$ & $\begin{array}{l}\text { ood Ratio test vs. OLS } \\
\text { ssion }\end{array}$ & $\begin{array}{l}\text { chibar2(01 } \\
213\end{array}$ & & $<.001$ & $\begin{array}{l}\text { chibar2(1) } \\
163\end{array}$ & \begin{tabular}{l|l|}
$=$ & $<.001$
\end{tabular} & $\begin{array}{l}\text { chibar2(01) } \\
=159\end{array}$ & $<.001$ \\
\hline $\begin{array}{l}\text { Likeli } \\
\text { Mode }\end{array}$ & $\begin{array}{l}\text { Dod Ratio test (Preceding } \\
\text { vs. Next) }\end{array}$ & $x^{2}(5)=16 s$ & & $<.001$ & $x^{2}(9)=28$ & $<.001$ & $x^{2}(3)=4$ & 0.253 \\
\hline $\begin{array}{l}\mathrm{Not} \\
\text { fit; }\end{array}$ & $\begin{array}{l}=855 ; \text { Est. = Estimate; Std. } \\
=\text { Ordinary Least Squares }\end{array}$ & & & & & $\bar{n}$ & & . \\
\hline
\end{tabular}


The "block" or stepwise approach was used carry out the hierarchical linear modeling meant to establish effects of school characteristics. The process involved entering student level variables into the first block and the school level variables (selected school characteristics) into the second block. From the study, Table 5 indicates that all the five student characteristics were statistically significant; student gender (a1a, $\mathrm{p}=0.03$ ), student's prior achievement (a1c, $\mathrm{p}=0.012$ ), student's parent involvement in discussing academic issues (a2a, $\mathrm{p}<0.001)$ and student's parents involvement in attendance of school meetings (a2c, $p<0.001)$. This gives the implication that student characteristics influenced academic achievement. The findings of the study further suggest that introducing students' characteristics into the model reduced the random effect from 0.4116 to 0.3577 . The proportion of variation in students' academic achievement andthe resulting percent variation explained at the two levels was $0.0565+0.2869=0.3434$ or $34.34 \%$. The findings gives the implication that children whose parents were either involved in discussing academic issues (a2a), involved in provision of school requirements (a2b) or involved in attendance of meetings at school (a2c) performed better in KCSE examination than children whose parents were less involved. This probably suggests that there are some school related factors that need to be investigated.

To estimate the magnitude of the effects of school characteristics on students' academic achievement, the researcher adopted criterion set by Hox (1995) where absolute values of standardized coefficients were ranked in terms of their relative degree of influence on the outcome variable within the same sample. In addition, the study was guided by Hungi and Thuku (2010) and Ejakait, et al., (2016) who proposed that a standardized regression coefficient should be considered relatively more important if its magnitude when taken in absolute terms is $\geq 0.10$.

\section{DISCUSSIONS}

From this study, Table 3 gives the implication that school location has a negative correlation with students' academic achievement in KCSE examination $(r=-0.219$, $\mathrm{p}<0.001)$. Thus, students who attended rural schools scored lower grades in KCSE examination compared with their counterparts who attended urban schools. This finding was consistent with Nyamongo (2014). The findings of the study also depicted that there was a positive correlation between school enrolment (class size) and students' academic achievement in KCSE examination $(r=0.304, p<0.001)$. The finding gave the implication that large schools performbetter in KCSE examinations. This was a classic departure from the findings of Akabogu and Ajiwoju (2014) who reported that large class had a statistically significant but negative effect on students' academic achievement. Waita (2012) also found that there was a statistically significant negative correlation between class size and academic achievement.
Table 4 depicts that the between school variance in academic achievement was 0.5426 and the within school- between-student variance in students' academic achievement was 0.4116 . These findings suggested that a larger proportion of the variation in students' academic achievement was accounted for by schools. In addition, the total variance in the students' academic variable when partitioned into the within group and between group variance components using the unconditional model wase $e_{i j}+u_{=}=0.4116+0.5426=$ 0.9542 or $95.42 \%$. This gives the impression that the model left about $4.58 \%$ of the variation unexplained. The probable cause of this was that some variables had been left out of the study. Future studies could therefore consider having more variables being considered.

In addition, from this study, Table 5 suggests that school characteristics particularly school size, type and location were not statistically significant. The results suggest that school characteristics modeled in the study explained for approximately 0.0787 or $7.89 \%$ of the variation in students' academic achievement at school level. These results give the impression that school characteristics had very small influence on the students' academic achievement. Findings of this study sharply contradict Koroye (2016) and Ejaakait, et al., (2016) who reported that there was a statistically significant relationship between type and location of a school and student academic achievement. Based on criteria set by Hox (1995), Ejakait et al., (2016) as well as Hungi and Thuku (2010) findings of this study suggest that location of schools and type of school were not predictors of academic achievement. This study concurs with Othman and Abdullah (2013).

But, when school non -teacher inputs were introduced alongside student level variables and school characteristics variables, school non teacher variables returned statistically significant and then the proportion of variation in students' academic achievement explained by student characteristics improved from 0.0567 to 0.0578 . This implies that school non teacher variables such as text books and physical facilities influenced students academic achievement In total, student and school characteristics accounted for up to $0.4280(42.80 \%)$ of the variation in academic achievement. In this study, even though the school characteristics modeled had no statistically significant effects on academic achievement, schools still accounted for 0.3702 out of the 0.5686 $\left.(0.3702 / 0.5686)^{*} 100=65.11 \%\right)$ of the variance available for explanation.

\subsection{CONCLUSION AND POLICY IMPLICATIONS}

Every beginning of the year parents struggle to look for "better" schools for their children based on the school characteristics such as type, location and class size. Many parents in Kenya are very keen on certain characteristics of the school their children are admitted preferring urban and single sex schools. Findings of this 
study gave the implication that type of school and location has no significant effect on students' academic achievement. Parents should therefore not have the perception that the type (boarding, day, mixed or coeducational) or location (rural or urban) of a school influences their children's academic achievement. These findings have policy implications for the Kenyan government which is supporting creation of day secondary schools. The study confirmed that day schools which are generally cheap may go a long way to increase access but will not compromise students' academic achievement.

\section{Statement of Competing Interest}

The Author has no competing interest

\section{REFERENCES}

Abreh, K.M (2015). Influence of wing schools: Complementary Basic Education Programme on Provision of Educational Opportunities in Northern Region of Ghana. (PhD Thesis). University of Nairobi, Kenya

Adeoye, M. Y., and Tayo, A. J. (2010). The Influence of school sex, location and type on students' academic performance. 3(1): 21-25. Journal of Science and Education.

Akabogu, J.U., and Ajiwoju, J.A. (2014). Effect of gender and school location on secondary school students achievement English vocabulary in junior secondary schools. International Journal of Research in Humanities, Arts and Literature. 6(2), 332-334.

Anditi, Z.O., Okere, M.O and Muchiri, R.D (2014). Influence of school characteristics on the achievement of secondary school chemistry students in the cognitive science process skill of evaluation in Kenya. European Journal of Educational Research.

Brock, T. (2016). Young adults and higher education: Barriers and breakthroughs to success. The Future of Children, 20(1), 109-132.

Coleman, J.S. (1966). Equality of education opportunity (Coleman) Study (EEOS). Washington, DC: Department of Health, Education, and Welfare, Office of Education/National Center for Education Statistics

Dambutzo, I. I. (2013). Factors in academic performance: Do moderator variables account for any significant differences in emotional self concepts and academic achievement of adolescents in secondary schools: Greener Journal of Social Sciences. 3 (9): 410-422.

Ejakait, E., Olel, M., Othuon, L., and Khasenye, O. (2016). A hierarchical linear modeling of teacher effects on academic achievement in Kenya
Certificate of Primary Education examination. American Journal of Educational Research Vol. 4(14) 1030-1040.

Gul, F., and Shaheen, F. (2014). Socioeconomic status and achievement: A survey of students at secondary school level. International Journal of Educational Studies.

Hox, J. J. (2010). Multilevel analysis: Techniques and applications (Second edition). New York: Routledge.

Hungi, N., and Thuku, F.W. (2010). "Differences in pupil achievement in Kenya: implications for policy and practice." International Journal of Educational Development, 30: 33-44. http://dx.doi.org/10.1016/j.ijedudev.2009.05.001.

Kang, N., Lee, S., and Niederle, M., (2014). Do single sex schools make a difference? Economic letters. http://dx.doi.org/10.1016/j.econlet.

Koroye, T. (2016). The influence of school physical environment on secondary school students' academic performance in Bayelsa State. Asian Journal of Education Researchwww.multidisciplinaryjournals.com.

Leckie, G., Three-Level Multilevel Models. 2013, Bristol, UK: Centre For Multilevel Modelling, University of Bristol.

Mersch, R.D. (2012). Student Academic Achievement in Rural vs. Non-Rural High Schools in Wisconsin. PhD Dissertation.

Mburu, N.P. (2013). Effects of types of school attended on students academic performance in Kericho and Kipkelion Districts, Kenya. International Journal of Humanities and Social Sciences, Vol.3(4): 44-47.

Mege, C.A. (2014). Influence of School Environmental Factors on Teaching Learning Processes in Public Primary Schools in Lower Nyokal Division, Homa Bay District, Kenya (Med Project). University of Nairobi, Nairobi Kenya.

Ndiritu, J. K (2012). Optimal Size and Existence of Economies of Scale in Public Secondary Schools in Nyandarua District, Kenya. Med Thesis (Unpublished). Kenyatta University, Nairobi Kenya.

Nyamongo, D.N. (2014). Relationship between schools based factors and students performance in Kenya certificate of secondary examination in Masaba district, Nyamira County, Kenya (Masters Thesis). Egerton University, Nakuru, Kenya

OECD (2010). PISA 2009 Results: What students know and can do: Student performance in reading, mathematics and science (Volumel), OECD Publishing.

Omotade, A.A., and Olusola, A.R. (2014). Impact of school location on academic achievement of science students in senior secondary school certificate examination. International Journal of Scientific and Research publications. Volume 4(9): 136-139.

Odumbe,G.A., Simatwa, E M.W and Ayodo T.M.O. (2013).Factors Influencing Student Academic Performance in Day-Secondary Schools in Kenya. A Case Study of Migori Sub County. Greener 


\section{Journal of Educational Research} (http://doi.org/10.15580/ 2015.3.071815099).

Raudenbush, S.W., and. Bryk. A.S. (2002). Hierarchical Linear Models: Application and data analysis methods. Thousand Oaks, California: Sage Publications, Inc.

Sugden, J. (2012). Girls get better results at singlegender State schools. The times (London,UK). http://www.timesonline.co.uk/tol/news/uk/education/ article v5927472.ece.

Saidin, N. and Brahim, M.F. (2013). No girls for me mummy: Providing a positive language learning environment for boys in single gender classes. Procedia-Social and behavioural Sciences, 38 (2012).

Waita J. K. (2012). Pupil-Teacher Ratio and its impact on academic performance in public primary schools in central Division, Machakos County, Kenya. Med Thesis, Kenyatta University, Kenya.

Zhahibimana, N. (2010). Effect of school type on students' academic achievement among high school students in Rwanda. Journal of Educational and Social Research Vol. 4 (2): 12-13.

Cite this Article: Echaune M. (2018). A Hierarchical Linear Modeling of the Effects of School characteristics on Students' Academic Achievement in Busia County, Kenya. Greener J Edu Res, 8(2): 35-46, http://doi.org/10.15580/GJER.2018.2.030818036. 